\title{
Aspergillus 6V4, a Strain Isolated from Manipueira, Produces High Amylases Levels by Using Wheat Bran as a Substrate
}

\author{
Jessyca dos Reis Celestino, ${ }^{1}$ Ana Caroline Duarte, ${ }^{2}$ Cláudia Maria de Melo Silva, ${ }^{1}$ Hellen \\ Holanda Sena, ${ }^{1}$ Maria do Perpétuo Socorro Borges Carriço Ferreira, ${ }^{1}$ Neila Hiraishi \\ Mallmann, ${ }^{1}$ Natacha Pinheiro Costa Lima, ${ }^{1}$ Chanderlei de Castro Tavares, ${ }^{1}$ Rodrigo Otávio \\ Silva de Souza, ${ }^{1}$ Érica Simplício Souza, ${ }^{3}$ and João Vicente Braga Souza ${ }^{2}$ \\ ${ }^{1}$ Universidade Federal do Amazonas, UFAM, Faculdade de Ciências Farmacêuticas, Manaus, AM, Brazil \\ ${ }^{2}$ Instituto Nacional de Pesquisas da Amazônia, INPA, Laboratório de Microbiologia Médica, Manaus, AM, Brazil \\ ${ }^{3}$ Universidade Estadual do Amazonas, UEA, Escola Superior de Tecnologia, Manaus, AM, Brazil
}

Correspondence should be addressed to João Vicente Braga Souza; joaovicentebragasouza@yahoo.com.br

Received 14 September 2013; Revised 3 January 2014; Accepted 16 January 2014; Published 2 March 2014

Academic Editor: Denise Freire

Copyright (C) 2014 Jessyca dos Reis Celestino et al. This is an open access article distributed under the Creative Commons Attribution License, which permits unrestricted use, distribution, and reproduction in any medium, provided the original work is properly cited.

\begin{abstract}
The aim of this study was screening fungi strains, isolated from manipueira (a liquid subproduct obtained from the flour production of Manihot esculenta), for amylases production and investigating production of these enzymes by the strain Aspergillus 6V4. The fungi isolated from manipueira belonged to Ascomycota phylum. The strain Aspergillus 6V4 was the best amylase producer in the screening assay of starch hydrolysis in petri dishes (ASHPD) and in the assay in submerged fermentation (ASbF). The strain Aspergillus $6 \mathrm{~V} 4$ produced high amylase levels $(335 \mathrm{UI} / \mathrm{L})$ using wheat bran infusion as the exclusive substrate and the supplementation of this substrate with peptone decreased the production of this enzyme. The moisture content of $70 \%$ was the best condition for the production of Aspergillus 6V4 amylases (385 IU/g) in solid state fermentation (SSF).
\end{abstract}

\section{Introduction}

Amylases are enzymes with industrial importance. They have been used for the saccharification of starch in activities such as baking, fuel production, sugar production, and the textile and paper industries [1]. These enzymes are produced by most plants, animals, and microorganisms. However, the enzymes currently available are obtained through biotechnological bioprocesses utilizing microorganisms such as Aspergillus sp. and Bacillus sp. Some of these enzymes have special characteristics such as a tolerance to temperature and the bioprocesses from which they are produced are economically viable [2].

The literature describes innumerous amylases; however, the $\alpha$-amylase, $\beta$-amylase, and glucoamylase are the most important economically. The $\alpha$-amylase (1,4- $\alpha$-glucan 4-glucanohydrolase, EC 3.2.1.1.) is an enzyme that breaks the connections $\alpha(1,4)$ from polysaccharides which have three or more units of D-glucose [3]. The attack occurs at various points of the chain simultaneously and the first hydrolysis products are always oligosaccharides of 5-7 glucose units. The $\beta$-amylase hydrolyzes the glycosidic linkages from the nonreducing end of the polysaccharides separating two glucose units and forming $\beta$-maltose [4]. The amyloglucosidase or glucoamylase $(1,4)(1,6)-\alpha$-D-glucan glucanohydrolase, EC 3.2.1.3 breaks $\alpha-1.4$ and $\alpha-1.6$ bonds from the nonreducing end $[3,5]$.

In the Amazon rain forest the vegetal biomass is rapidly degraded by microbes; this is due to weather conditions, humidity, substrate abundance, and the potential of microorganisms in producing enzymes [6]. The cassava (Manihot esculenta) is an important source of food for the Amazon 
population and it is, as well as it's by-products, potential good substrates for searching amylolytic microorganisms. The aim of this study was screening fungi strains, isolated from manipueira (a liquid subproduct obtained from the flour production of Manihot esculenta), for amylases production and investigating production of these enzymes by the strain Aspergillus 6V4.

\section{Materials and Methods}

2.1. Fungi Isolation. Approximately $1 \mathrm{~mL}$ of manipueira (a liquid subproduct obtained from the flour production of Manihot esculenta) was subjected to successive dilutions $\left(1 \times 10^{-1}-1 \times 10^{-5}\right)$ and $100 \mu \mathrm{L}$ aliquots was plated on a medium composed of $1.0 \%$ soluble starch, $0.25 \%$ peptone, and $0.25 \%$ yeast infusion. The plates were incubated at $35^{\circ} \mathrm{C}$ and monitored daily over 5 days for isolation of filamentous fungi. The isolated colonies were purified and stored in potato dextrose agar (PDA) at $7^{\circ} \mathrm{C}[7]$.

2.2. Screening 1: Assay of Starch Hydrolysis in Petri Dishes (ASHPD). The radial growth and the halo of starch hydrolysis were observed during the growth of the strains in a culture medium that has starch as the main carbon source $(1.0 \%$ soluble starch, $0.25 \%$ peptone, and $0.25 \%$ yeast infusion). The observation of hydrolysis halos was undertaken with a $1 \%$ iodine solution [8].

2.3. Screening 2: Assay in Submerged Fermentation (ASbF). The strains were submitted to a submerged bioprocess in order to evaluate the production of extracellular amylases [7]. $20 \mathrm{~mL}$ of medium composed of $1.0 \%$ soluble starch, $0.25 \%$ peptone, and $0.25 \%$ yeast infusion was placed into $125 \mathrm{~mL}$ Erlenmeyer flasks; this was inoculated with $1 \times 10^{5}$ cell $/ \mathrm{mL}$. The bioprocess was conducted at $35^{\circ} \mathrm{C}$, with orbital agitation (150 rpm), for 72 hours. The fermented material was centrifuged at $10,000 \mathrm{~g}$ for $10 \mathrm{~min}$ and the supernatant was used for the determination of amylase activity.

2.4. Amylases Production Submerged Fermentation Using Wheat Bran as the Substrate and the Influence of Peptone Supplementation in the Enzyme Activity. The strain selected in the screening assays (Sections 2.2 and 2.3) was submitted to a submerged bioprocess using wheat bran infusion as the substrate. The wheat bran infusion was chosen as substrate since we believe that the hot water is able to extract the soluble starch from the wheat bran allowing the separation of this component leading to the amylases induction. $50 \mathrm{~mL}$ of wheat bran infusion ( $60 \mathrm{~g}$ of wheat bran was mixed with $1 \mathrm{~L}$ of water at $80^{\circ} \mathrm{C}$ and then filtered with gauze) was transferred to $125 \mathrm{~mL}$ Erlenmeyer flasks. A spore's suspension was prepared and the culture medium was inoculated with $1 \times$ $10^{4}$ spores $/ \mathrm{ml}$. The Erlenmeyers were incubated in an orbital shaker $(100 \mathrm{rpm})$ at room temperature for 96 hours. Samples were collected every 24 hours in order to evaluate the biomass production (dry weight) and the amylases production. The effect of the culture medium supplementation with peptone $5 \%(\mathrm{w} / \mathrm{w})$ was investigated.
2.5. Amylase Production in Solid State Fermentation (SSF). Wheat bran (15 g) was added to $250 \mathrm{~mL}$ Erlenmeyer flasks; this substrate was moisturized and inoculated with the strain selected in the screening assays (Sections 2.2 and 2.3), $1 \times 10^{4}$ spores $/ g$. The bioprocess was incubated at room temperature for 96 hours. These experimental conditions evaluated the influence of moisture contents of $50,60,70$, and $80 \%$ in amylases production. The enzymes were extracted by adding $1 \mathrm{~g}$ of the SSF to $10 \mathrm{~mL}$ water in an Erlenmeyer flask and incubating it in orbital agitation (100 rpm) for 30 minutes.

2.6. Determination of Amylase Activity. The reaction mixture consisted of $30 \mu \mathrm{L}$ enzymatic solution (culture filtrate) and $30 \mu \mathrm{L}$ substrate solutions (soluble starch in $0.2 \mathrm{M}$ acetate buffer, $\mathrm{pH}$ 5.0). This mixture was incubated at $42^{\circ} \mathrm{C}$ for 30 minutes; this reaction was stopped by adding $200 \mu \mathrm{L}$ of $0.2 \mathrm{M} \mathrm{HCl}$. The reaction then received $40 \mu \mathrm{L}$ of iodine solution $\left(0.30 \% \mathrm{KI}, 0.03 \% \mathrm{I}_{2}\right)$. The control was prepared according to the procedure described above but the enzyme was replaced by an equivalent volume of distilled water (control substrate). Another control was performed by replacing the starch solution per the same volume of acetate buffer control (enzyme). The absorbance was determined at $600 \mathrm{~nm}$ in a spectrophotometer. One unit of amylase activity was defined as the amount of enzyme required to hydrolyze $1.0 \mathrm{mg}$ of starch per minute under the assay conditions [9].

\section{Results}

The cassava flour byproducts were not previously well studied as a source of amylase producers. In the fungal isolation a culture medium containing starch was used as the main carbon source. 20 cultures from mitosporic fungi were obtained; they belonged to Ascomycota phylum with most of them belonging to the genera Aspergillus and Penicillium.

In order to select a strain able to produce high levels of amylase, two different screening assays were carried out, $A S H P D$ and $A S b F$. In the ASHPD, all isolates produced amylases and ten of them produced an enzymatic index greater than 1.5 (Table 1). In the $A S b F$ the amylase activities ranged from 2.0 to $36.2 \mathrm{IU} / \mathrm{L}$ (Table 1). The strain Aspergillus 6V4 was selected for the next stages of this study for presenting one of the highest amylase production in ASbF.

An infusion obtained from wheat bran was used as the substrate for amylase production; the infusion was obtained through infusion and a Sbf was carried out with the strain Aspergillus 6V4. The maximum enzymatic activity (335 U/L) was obtained at $96 \mathrm{~h}$ (Figure 1).

In order to investigate if wheat bran was an adequate substrate for amylase production, an experiment evaluating the influence of the supplementation with peptone was carried out. The supplementation of $5 \mathrm{~g} / \mathrm{kg}$ resulted in the decreased the amylase activity in $14,3 \%$.

Whilst assessing the influence of the moisture in the production of amylase in SSF, it was observed that $70 \%$ moisture was the best condition (Figure 2). 
TABLE 1: Results of amylase production by the isolated strains in the assay of starch hydrolysis in petri dishes (ASHPD) and in the assay in submerged fermentation (ASbF).

\begin{tabular}{|c|c|c|}
\hline Isolates & $\begin{array}{c}\text { ASHPD } \\
\text { Enzyme index } \\
(\mathrm{mm} / \mathrm{mm})^{*}\end{array}$ & $\begin{array}{c}\text { ASbF } \\
\text { Amilase activity } \\
(\mathrm{IU} / \mathrm{L})\end{array}$ \\
\hline Penicillium 1B10-5 & 1.90 & $28 \pm 2$ \\
\hline Penicillium 2B10-5 & 1.3 & $10 \pm 4$ \\
\hline Aspergillus 3V10-5 & 1.1 & $19 \pm 9$ \\
\hline Fusarium 4V10-5 & 1.1 & $25 \pm 7$ \\
\hline Aspergillus 5V10-5 & 1.1 & $10 \pm 2$ \\
\hline Penicillium 6V10-5 & 1.35 & $19 \pm 1$ \\
\hline Penicillium 7V10-5 & 1.78 & $2.0 \pm 0.3$ \\
\hline Aspergillus 8V10-3 & 1.26 & $12 \pm 3$ \\
\hline Paecilomyces 9V10-5 & 1.75 & $12 \pm 5$ \\
\hline Aspergillus 10V10-5 & 1.74 & $32 \pm 0.1$ \\
\hline Aspergillus 1V-4 & 1.55 & $12.5 \pm 0.4$ \\
\hline Aspergillus 2V-5 & 1.39 & $7.4 \pm 0.4$ \\
\hline Aspergillus 3V-5 & 2.2 & $33 \pm 4$ \\
\hline Aspergillus 4V-5 & 1.90 & $2.4 \pm 0.6$ \\
\hline Aspergillus 5V-4 & 1.54 & $15 \pm 9$ \\
\hline Aspergillus 6V4 & 1.90 & $36.2 \pm 2$ \\
\hline Penicillium 7V-4 & 1.58 & $32.5 \pm 0.3$ \\
\hline Penicillium 8V-4 & 1.34 & $10 \pm 5$ \\
\hline Aspergillus 9V-5 & 1.29 & $11 \pm 2$ \\
\hline Aspergillus 10V-5 & 1.37 & $15 \pm 3$ \\
\hline
\end{tabular}

* (Diameter of colony + Halo hydrolysis)/(diameter of colony).

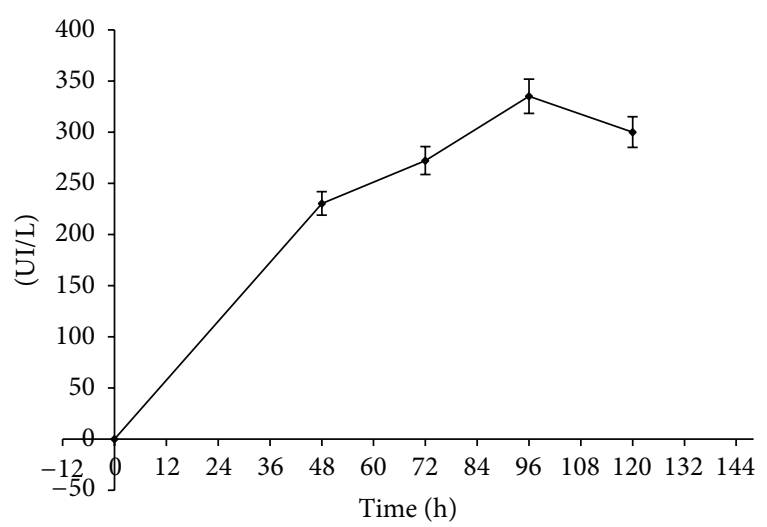

FIgUre 1: Production of amylase from Aspergillus 6V4 in SbF using the wheat bran infusion as substrate.

\section{Discussion}

The microorganisms isolated in this study were from the Ascomycota phylum; such groupings are known as good amylases producers. The Aspergillus spp. has been used for production of amylases that are currently on the market; these genera produce over 200 extracellular enzymes and several of these have industrial importance $[10,11]$.

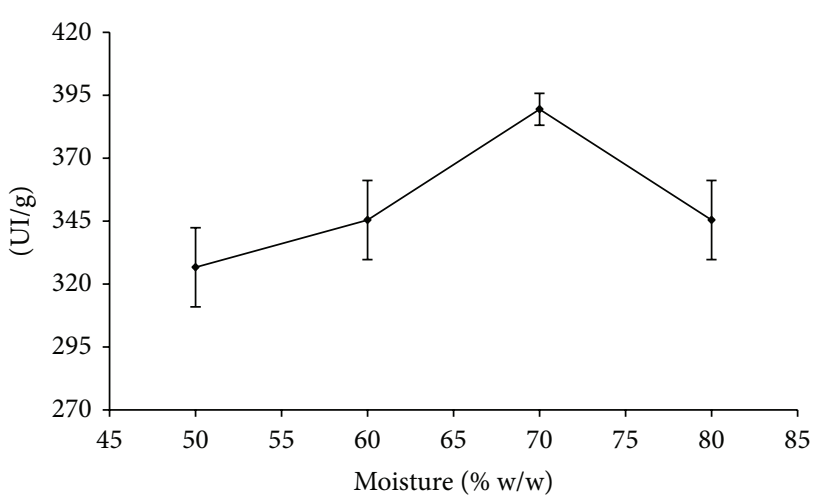

Figure 2: Production of Aspergillus amylases 6V4 in SSF using wheat bran as the substrate containing different moisture.

The index assay (assay plates) did not correlate with the results of amylase production in a liquid medium (regression $R^{2}=0.09$ ). This discrepancy can be explained since the study in agar plates has a different environmental condition from that carried out in the submerged bioprocess [12]. The screening assay showed amylases production from 2.0 to $36.2 \mathrm{IU} / \mathrm{L}$. These enzyme concentrations are low; however, they were obtained from experiments that were not optimized. The strain Aspergillus 6V4 had the highest enzyme production and was selected for the remaining experiments.

The Aspergillus 6V4 colonies presented masses of yellowgreen spores on the upper surface and reddish-gold on the lower surface. It's hyphal occurred by thread-like branching and produced mycelium. The hyphae were spetade and hyaline and it was observed conidiophores (colorless) and conidiaspores in phialides uniseriate and biseriate. This morphological information included this microorganism in the Aspergillus flavus group. The ITS region of his rDNA has been investigated in order to define specie.

Agroindustrial residues have been used in research bioprocesses as a substrate because they are relatively inexpensive and they have an appropriated content of carbon and nitrogen sources $[9,13,14]$. In the present work, a wheat bran infusion was used for producing amylases by SbF with Aspergillus 6V4. This strategy resulted in the increase of amylase production $(335 \mathrm{IU} / \mathrm{L})$ in 9.25 times. This amylase level is comparable to that described in other studies $[15,16]$ and this demonstrates that the wheat bran is a suitable substrate. The supplementation of wheat bran infusion with peptone decreased the production of amylases. This is probably a result of the effect of metabolic repression and demonstrates that the wheat bran infusion has nitrogen sources in the desirable amount for the enzyme production $[9,13,14]$.

The solid state bioprocess has been evaluated for the production of enzymes which are of industrial interest. They allow the use of agroforestry residues and exhibit both higher productivity and lower operational costs [17]. Under the experimental conditions $385 \mathrm{IU} / \mathrm{g}$ was produced. Comparing SbF with SSF, the latter produced more enzyme in $1 \mathrm{~g}$ of solid state medium than what was observed in a $1 \mathrm{~L}$ of submerged fermentation medium. Similar results have previously been 
demonstrated by [17]. The moisture trial demonstrated that $70 \% \mathrm{w} / \mathrm{w}$ was the best for amylase production. This result agrees with previous studies that showed that moisture content of approximately $70 \%$ was the most suitable for the production of enzymes which are of industrial interest.

Optimized production and characterization of the enzymes produced by the microorganism isolated in this study are presented as an appropriate strategy to more adequately evaluate the biotechnological potential of this new source of amylases $[14,18]$. This work demonstrated that cassava byproducts can be used as a source of amylase producers; the organisms isolated from these substrates belonged to Ascomycota phylum and the strain Aspergillus $6 \mathrm{~V} 4$ produced high amylase levels and needs to be further investigated.

\section{Conflict of Interests}

The authors declare that there is no conflict of interests regarding the publication of this paper.

\section{Acknowledgments}

The authors thank FAPEAM for financial support.

\section{References}

[1] A. Pandey, P. Nigam, C. R. Soccol, V. T. Soccol, D. Singh, and R. Mohan, "Advances in microbial amylases," Biotechnology and Applied Biochemistry, vol. 31, no. 2, pp. 135-152, 2000.

[2] R. Gupta, P. Gigras, H. Mohapatra, V. K. Goswami, and B. Chauhan, "Microbial $\alpha$-amylases: a biotechnological perspective," Process Biochemistry, vol. 38, no. 11, pp. 1599-1616, 2003.

[3] A. Pandey, C. Webvb, C. R. Soccol, and C. Larroche, Enzyme Technology, Asiatech Publishers, New Delhi, India, 2005.

[4] M. Vihinen and P. Mäntsälä, "Microbial amylolytic enzymes," Critical Reviews in Biochemistry and Molecular Biology, vol. 24, no. 4, pp. 329-418, 1989.

[5] L. L. Lin, C. C. Chyau, and W. H. Hsu, "Production and prop erties of a raw starch-degrading amylase from the thermophilic and alkalophilic Bacillus sp. TS-23.Biotechnol," Applied Biochemistry and Biotechnology, vol. 28, part 1, pp. 61-68, 1998.

[6] J. V. B. Souza, É. S. Silva, M. L. S. Maia, and M. F. S. Teixeira, "Screening of fungal strains for pectinolytic activity: endopolygalacturonase production by Peacilomyces clavisporus 2A.UMIDA.1," Process Biochemistry, vol. 39, no. 4, pp. 455-458, 2003.

[7] E. Gomes, S. R. Souza, R. P. Grandi, and R. D. Silva, "Production of thermostable glucoamylase by newly isolated Aspergillus flavus a 1.1 and Thermomyces lanuginosus a 13.37," Brazilian Journal of Microbiology, vol. 36, no. 1, pp. 75-82, 2005.

[8] M. R. Spier, "Produção de Enzimas Amilolíticas Fúngicas alfaamilase e Amiloglucosidase por fermentação no estado sólido," 2005.

[9] T. N. Nwagu and B. N. Okolo, "Extracellular amylase production of a thermotolerant $v$ sp. isolated from Eastern Nigerian soil," Brazilian Archives of Biology and Technology, vol. 54, no. 4, pp. 649-658, 2011.
[10] A. M. Castro, T. V. Andréa, L. Reis Castilho, and D. M. G. Freire, "Use of mesophilic fungal amylases produced by solidstate fermentation in the cold hydrolysis of raw babassu cake starch," Applied Biochemistry and Biotechnology, vol. 162, no. 6, pp. 1612-1625, 2010.

[11] P. M. Souza and P. O. Magalhães, "Application of microbial aamilase in industry-a review," Brazilian Journal of Microbiology, vol. 41, no. 4, pp. 850-861, 2010.

[12] K. Salahuddin, R. Prasad, S. Kumar, and M. D. Visavadia, "Isolation of soil thermophilic strains of actinomycetes for the production of $\alpha$-amylase," African Journal of Biotechnology, vol. 10, no. 77, pp. 17831-17836, 2011.

[13] S. A. Mohamed, E. I. Azhar, M. M. Ba-Akdah, N. R. Tashkandy, and T. A. Kumosani, "Production, purification and characterization of $\alpha$-amylase from Trichoderma harzianum grown on mandarin peel," African Journal of Microbiology Research, vol. 5, no. 9, pp. 1018-1028, 2011.

[14] K. Tamilarasan, C. Muthukumaran, and M. Dharmendira Kumar, "Application of response surface methodology to the optimization of amylase production by Aspergillus oryzae MTCC 1847," African Journal of Biotechnology, vol. 11, no. 18, pp. 4241-4247, 2012.

[15] E. R. Santos, Z. N. S. Teles, N. M. Campos, D. A. J. Souza, A. S. R. Bispo, and R. P. Nascimento, "Production of a-amylase from Streptomyces sp. SLBA-08 strain using agro-industrial byproducts," Brazilian Archives of Biology and Technology, vol. 55, no. 5, pp. 793-800, 2012.

[16] A. D. Juwon and O. F. Emmanuel, "Experimental investigations on the effects of carbon and nitrogen sources on concomitant amylase and polygalacturonase production by Trichoderma viride BITRS-1001 in submerged fermentation," Biotechnology Research International, vol. 2012, pp. 1-8, 2012.

[17] S. B. Onofre, S. A. Groff, A. Sartori et al., "Production of $\alpha$ Amylase and Amyloglucosidase by the Fungus Cylindrocladium sp. in semi-solid state fermentation," Journal of Microbiology Research, vol. 2, no. 5, pp. 123-126, 2012.

[18] H.-R. Kim, J.-H. Kim, D.-H. Bai, and B.-H. Ahn, "Identification and characterization of useful fungi with $\alpha$-amylase activity from the korean traditional nuruk," Mycobiology, vol. 39, no. 4, pp. 278-282, 2011. 

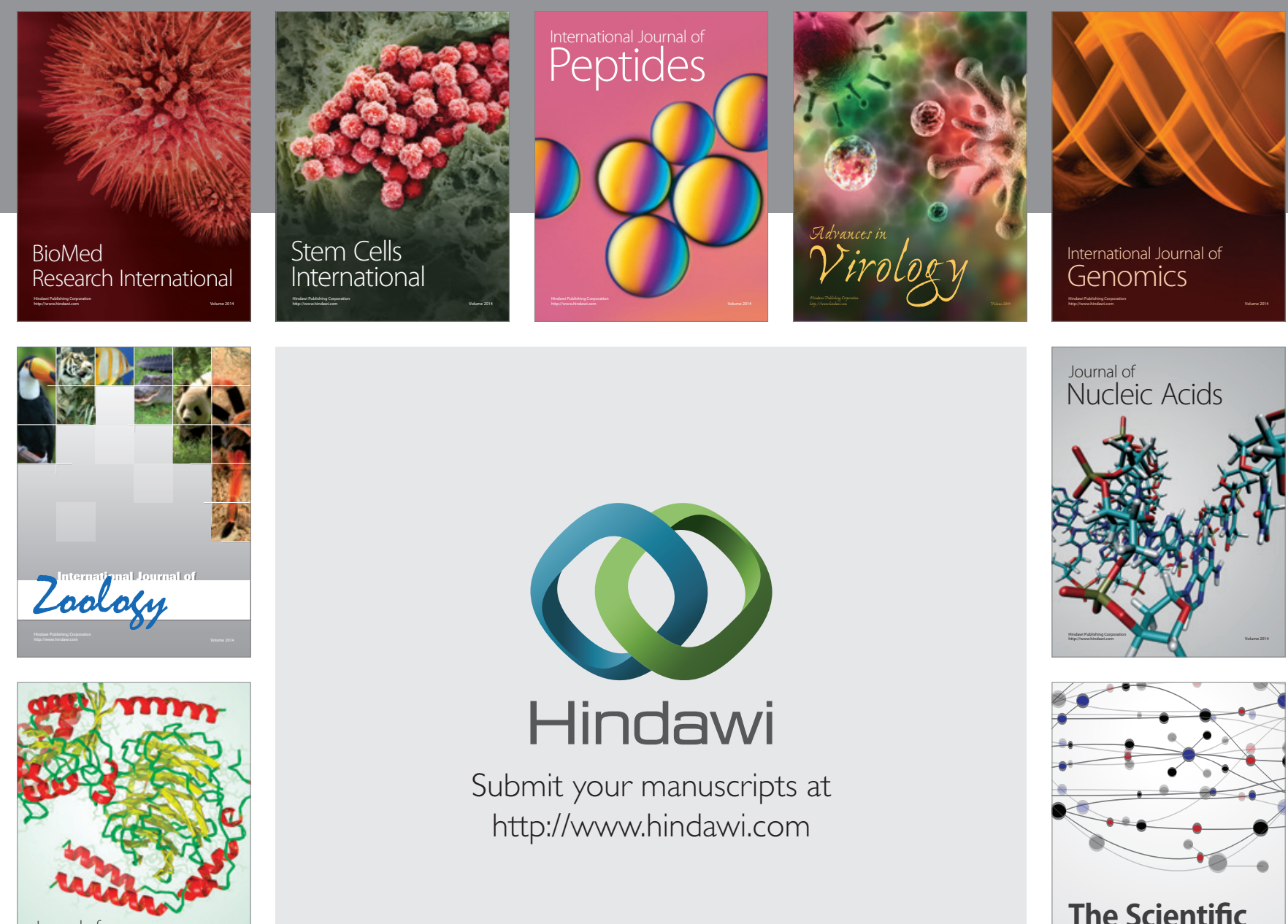

Submit your manuscripts at

http://www.hindawi.com

Journal of
Signal Transduction
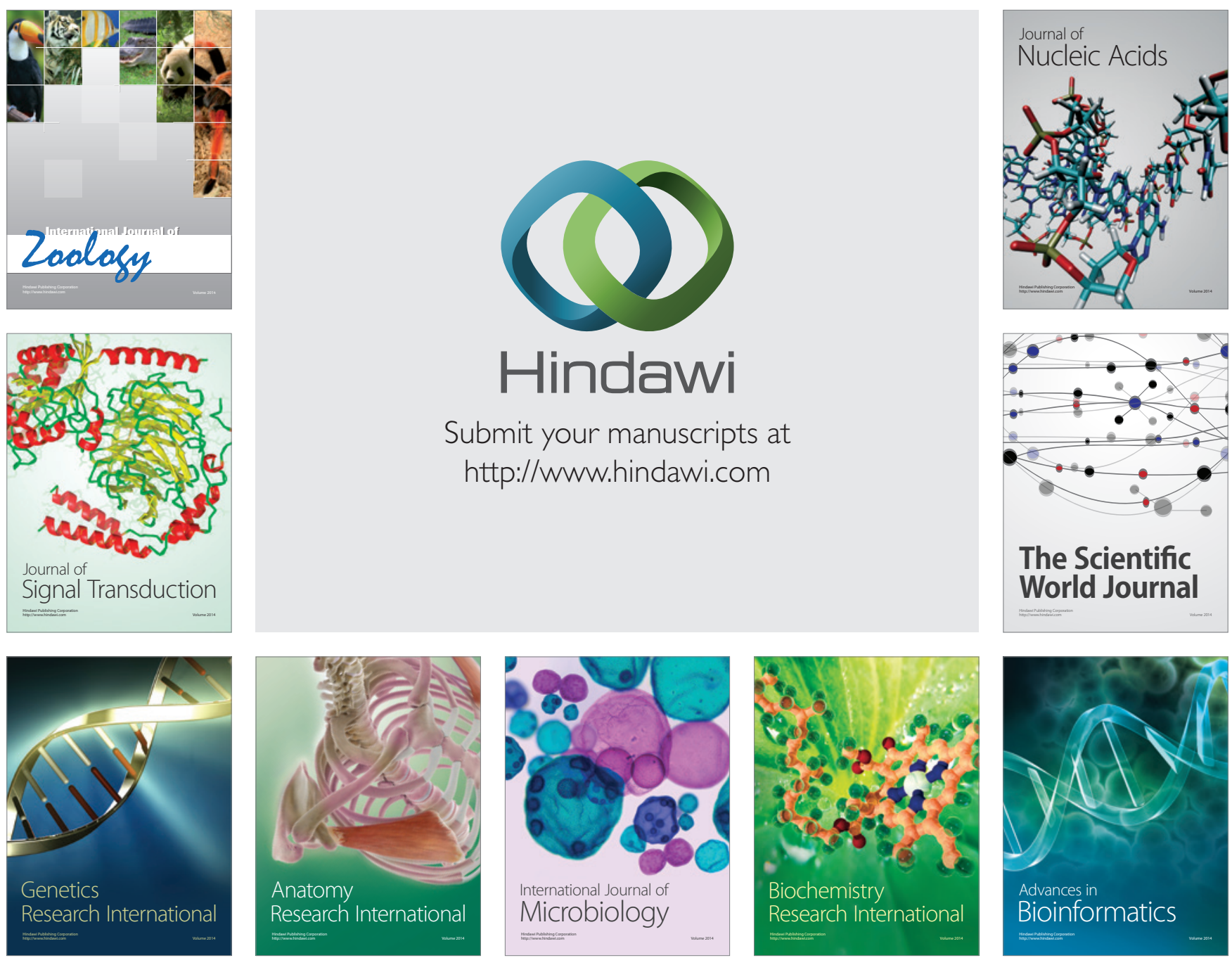

The Scientific World Journal
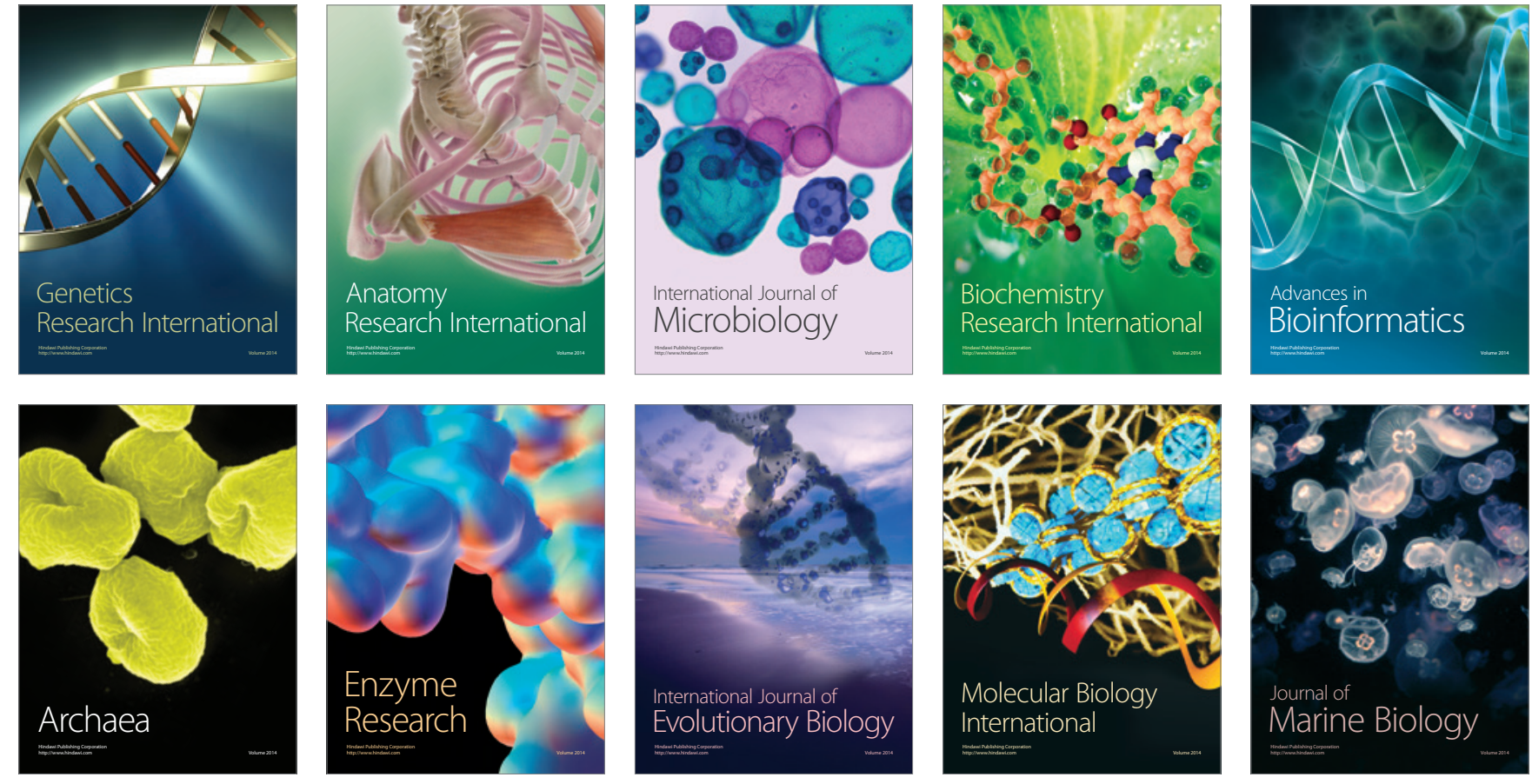